\section{NEW DISTRIBUTION RECORD OF SARCOPYRAMIS NAPALENSIS WALL. (MELASTOMATACEAE) FROM GARHWAL HIMALAYA, UTTARAKHAND, INDIA}

\section{J.K. Tiwari ${ }^{1}$, P. Tiwari ${ }^{2}$, Dinesh Singh Rawat ${ }^{3}$, Radha Ballabha ${ }^{4} \&$ C.S. Rana ${ }^{5}$}

1,2,3,4 Plant Systematics and Palynology Laboratory, Department of Botany \& Microbiology, HNB Garhwal University, Srinagar Garhwal, Uttarakhand 246174, India

${ }^{5}$ Dabur Research \& Development Centre (DRDC), Dabur India Limited Kaushambi, Sahibabad, Ghaziabad, Uttar Pradesh 201010, India ${ }^{1}$ jktiwari31@rediffmail.com, ${ }^{2}$ ptiwari29@rediffmail.com,

${ }^{3}$ dsrwt7@rediffmail.com (corresponding author),

${ }^{4}$ radhekuniyal.2007@rediffmail.com, ${ }^{5}$ drcsir@gmail.com

During the course of floristic exploration in Chamoli District (Uttarakhand State, India), the authors came across populations of Sarcopyramis Wall., growing in a shady moist locality of Panichhoya forest of Gairsain (Chamoli), on the right flank of river Ramganga. Critical examination revealed the plant as Sarcopyramis napalensis Wall. of Melastomataceae. Two populations ca. 150-200 individuals each were observed under the present study. So far, this species has been recorded in Arunachal Pradesh, Assam, Mizoram and Sikkim in eastern Himalaya and recently, its occurrence was reported in western Himalaya by Pusalkar (2013). The species has not been reported by earlier workers from Garhwal Himalaya (Duthie 1903; Babu 1977; Raizada \& Saxena 1978; Polunin \& Stainton 1984; Naithani 1984-85; Gaur 1999; Uniyal et al. 2007). Thus, this is the first report on the occurrence of Sarcopyramis napalensis Wall. in Garhwal Himalaya and an addition to the 'Flora of Chamoli' as well. The voucher specimen has been deposited at HNB Garhwal University Herbarium, Srinagar Garhwal, Uttarakhand (GUH 20736).

\section{OPEN ACCESS}

\section{Sarcopyramis napalensis (Images 1-2)}

Wall., Tent. Fl. Nepal. 1:32, t. 23. 1824; C.B. Clarke in Hooker. f., Fl. Brit. India 2: 540. 1883; S. subramanii M.P. Nayar, Proc. Indian Acad. Sci., B 66: 279. 1967; S. humilis M.P. Nayar, J. Bombay. Nat. Hist. Soc. 71: 170. 1974.

Specimen examined: GUH 20736, 19.viii.2014, Panichhoya forest, Chamoli, Garhwal Himalaya, India, coll. Dinesh Singh Rawat (Image 3).

Herb, erect, 15-20 cm tall, solitary or branched above. Stems 4-sided, succulent, glabrous. Leaves opposite, decussate, petiole $1-2 \mathrm{~cm}$, secondary veins 1 or 2 on each side of mid-vein, tertiary veins parallel; leaf blade broadly ovate-sub-lanceolate, $3-8 \times 2-3 \mathrm{~cm}$, membranous, often with white spots, base cuneatesub round and slightly decurrent, margin serrulate, apex acuminate. Inflorescence terminal cyme, nearly 3-5 flowered; bracts 2, sub-sessile, foliaceous, ovate; pedicel short, ca. $2 \mathrm{~mm}$, 4-angled, narrowly winged on angles. Hypanthium cupular-funnel form, ca. $5 \mathrm{~mm}$, 4-sided, usually winged on angles. Calyx lobes-4, ca. $1 \mathrm{~mm}$, apex usually truncate or with a fimbriate membranous disk. Petals 4, ca. $7 \mathrm{~mm}$, usually oblique, obovate, apex apiculate or truncate, pink-purplish. Stamens 8, equal in size, filament ca. $3 \mathrm{~mm}$ long, anthers ca. $1 \mathrm{~mm}$, dehiscence poricidal, yellow; connective

DOI: http://dx.doi.org/10.11609/jott.2818.8.5.8835-8836

Editor: K.S. Negi, NBPGR-ICAR, Nainital, India

Date of publication: 26 May 2016 (online \& print)

Manuscript details: Ms \# 04210 | Received 17 January 2015 | Final received 03 May 2016 | Finally accepted 07 May 2016

Citation: Tiwari, J.K., P. Tiwari, D.S. Rawat, R. Ballabha \& C.S. Rana (2016). New distribution record of Sarcopyramis napalensis Wall. (Melastomataceae) from Garhwal Himalaya, Uttarakhand, India. Journal of Threatened Taxa 8(5): 8835-8836; http://dx.doi.org/10.11609/jott.2818.8.5.8835-8836

Copyright: (C) Tiwari et al. 2016. Creative Commons Attribution 4.0 International License. JoTT allows unrestricted use of this article in any medium, reproduction and distribution by providing adequate credit to the authors and the source of publication.

Funding: None.

Conflict of Interest: The authors declare no competing interests.

Acknowledgement: The authors gratefully acknowledged the help and cooperation by Sri Ranjeet Singh Rawat of village Bukhali (Gairsain) during the field study. We are also thankful to Dr. D.S. Rawat, GBPUA\&T, Pantnagar and Dr. Gurcharan Singh, Associate Professor (Retired), SGTB Khalsa College, University of Delhi, for help in identification. 


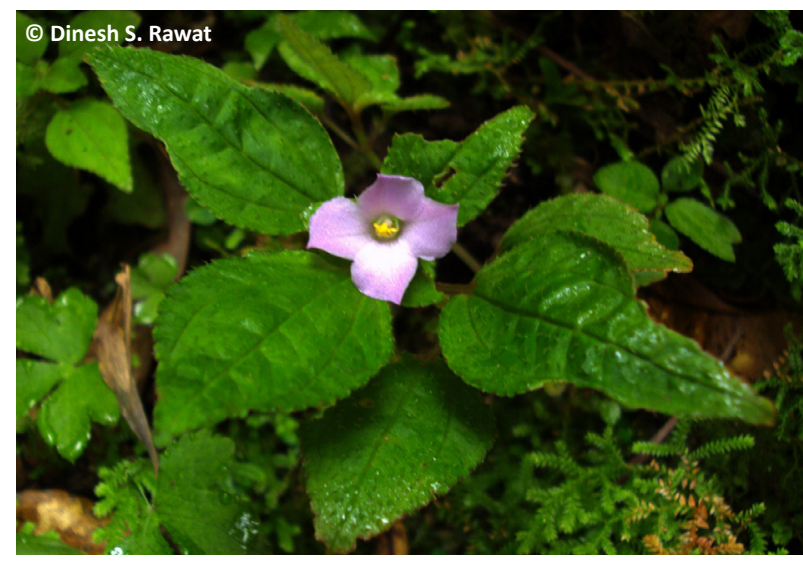

Image 1. Sarcopyramis napalensis at flowering

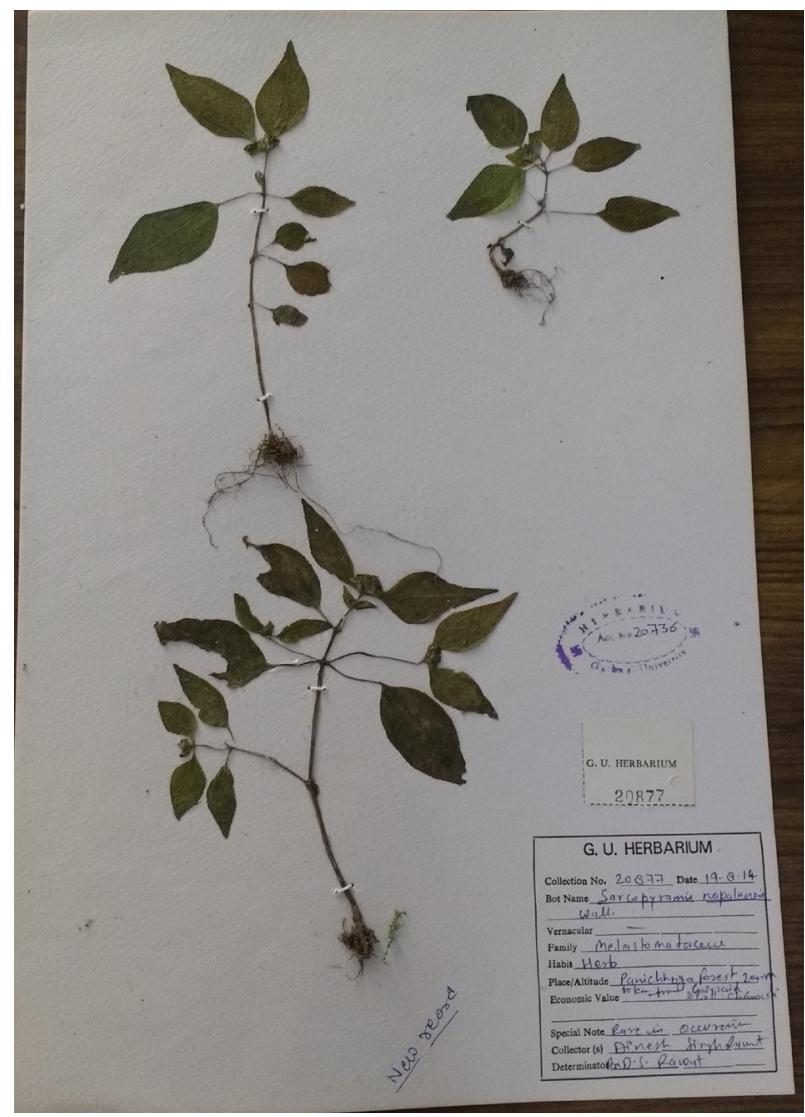

Image 3. Herbarium image of Sarcopyramis napalensis

decurrent, forming a short spur. Style ca. $2 \mathrm{~mm}$, stigma capitate. Ovary inferior. Capsule cup-shaped, 4-sided, crown exserted from hypanthium, membranous. Seeds small, numerous.

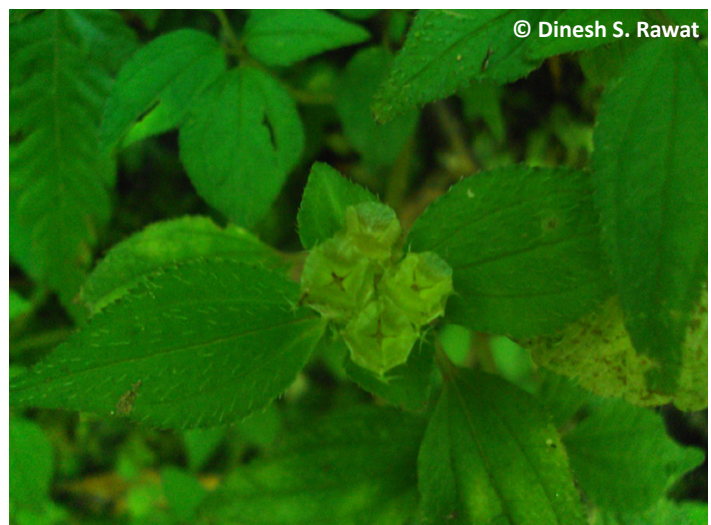

Image 2. Sarcopyramis napalensis at fruiting

Flowering \& Fruiting: August-September and October-November.

Ecology: Uncommon, shaded damp habitat or stream side, associated with species of Selaginella, Hydrocotyle, Pilea, in broad-leaved mixed Oak-Rhododendon (Quercus leucotrichophora - Rhododendon arboreum) forest.

Distribution: Bhutan, China, India (Arunachal Pradesh, Assam, Mizoram, Sikkim, Uttarakhand), Malesia, Myanmar, Nepal, Philippines and Thailand. At Birthi-Ruiger forest (2350-2425 m) of Pithoragarh (Kumaon) and Panichhoya forest (ca. 2000-2150 m), $10 \mathrm{~km}$ westward to Gairsain, district Chamoli (Garhwal) in Uttarakhand.

\section{References}

Babu, C.R. (1977). Herbaceous Flora of Dehradun. Council of Scientific and Industrial Reaserch, New Delhi, 184pp.

Duthie, J.F. (1903). Flora of the Upper Gangetic Plain and of the Adjacent Siwalik and Sub-Himalayan Tracts - Vol. 1. Superintendent of Government Printing, Culcutta, (Reprint. 2006, Bishen Singh Mahendra Pal Singh, Dehradun), 345pp.

Gaur, R.D. (1999). Flora of the District Garhwal North West Himalaya (with Ethnobotanical Notes). Transmedia, Srinagar Garhwal, India, $317 p p$.

Naithani, B.D. (1984-85). Flora of Chamoli. Botanical Survey of India, Howrah, 235pp.

Polunin, O. \& A. Stainton (1984). Flowers of the Himalaya. Oxford University Press, Delhi, India, 145pp.

Pusalkar, P.K. (2013). Sarcopyramis Wall. (Melastomataceae) - A new generic record for western Himalaya. BSI-ENVIS 18(2): 2-3.

Raizada, M.B. \& H.O. Saxena (1978). Flora of Mussoorie Vol. 1. Bishen Singh Mahendra Pal Singh, Dehradun, 247pp.

Uniyal, B.P., J.R. Sharma, U. Chaudhari \& D.K. Singh (2007). Flowering Plants of Uttarakhand (A Checklist). Bishen Singh Mahendra Pal Singh, Dehradun, 132pp. 